\title{
MULTIMODAL ANALYSIS ON SPRITE ADVERTISEMENT
}

\author{
Rahmawati ${ }^{1}$, Tengku Silvana Sinar ${ }^{2}$ \\ ${ }^{1}$ Universitas Prima Indonesia, Universitas Sumatera Utara, Medan, Indonesia \\ rahmawati@unprimdn.ac.id, tengkusilvana@usu.ac.id \\ Corresponding author: rahmawati@unprimdn.ac.id
}

\begin{abstract}
This study examines the multimodal analysis of Sprite ads. This study aims to see what multimodal is in the advertisement. The theory used in this study is a semiotic approach related to a multimodal system which includes linguistic, visual, audio, gestural, and spatial aspects (Anstey and Bull 2010; Bateman and Schmidt, 2012; and Chandler, 2007). The data are videos made in Indonesia and are 30 seconds long. Videos are analyzed based on five multimodal semiotic systems to understand and investigate the multi modes of communication within them.
\end{abstract}

Keywords: Analysis, Multimodal, Advertisment

\section{Introduction}

Advertising is one of the means used to promote certain products to attract people's attention (potential consumers) so that they want to get or buy the product. According to Kasali (1992: 9), advertising is part of the promotion mix and the promotion mix is part of the marketing mix. This clearly implies that advertising, promotion and marketing are three things that play a very important role or are the spearheads in the industrial world. Without these three things, the industrial world - both goods and services - will never work.

One of the texts that have the complexity of meaning is a good advertisement print media advertisements as well as media advertisements electronic. The complexity of meaning is due to convey the message in the ad not only used language elements but also elements of nonverbal language and other visual means. Therefore, to understand the complexity of meaning it is necessary to do deep multimodal analysis the ad.

The above exposure raises writer interest to analyze electronic media advertising, namely advertising on television. Ads that are analyzed are advertisements "SPRITE". Analyzes were carried out for describe a multimodal element contained in the ad.

Multimodal analysis emphasizes that all good means of communication verbal as well as nonverbal plays important role in giving rise mean. Because language contains meaning namely informative content (O'Halloran and Smith in Sinar, 2012: 133) said multimodal analysis including analysis all kinds of communication that have text interaction and integration of two or more semiotic sources or means communication to achieve functions communicative of the text.

Multimodal analysis discussed in this paper using theory functional systemic linguistics (LSF). A multimodal analysis model was developed from a blend of multimodal theory (Anstey \& Bull, 2010), and multimodal analysis by Kress and Van Leeuwen (1996-2006).

In the semiotic sense, signs are words, images, sounds, gestures, and objects (Chandler, 2007: 2). Meanwhile, Bateman and Schmidt (2012: 28) carry the terms language (spoken and written), visual, acoustic, and place as signs that are studied in semiotics. These various signs are also called multimodal, as stated by Anstey and Bull (2010), a text is said to be a multimodal text when the text has two or more semiotic systems. Overall there are five types of semiotic systems, namely: a). Linguistics: Contains aspects such as vocabulary, generic structure, and grammatical of spoken and written language. b) Visual: Contains aspects such as colors, vectors, points of view on stationary and moving objects. c) Audio: Contains aspects such as volume, high and low notes and rhythm of music and sound effects. d) Gestural: Contains aspects such as movement, speed, and silence in facial expressions and body language. 
d) Location: Contains aspects such as the proximity of the object, direction, position of the layout, and spacing based on the layout.

\section{Methodology}

This research used descriptive method because the researcher analyzed the data descriptively and the result was in a form of explanation. This research described the multimodal analysis using semiotic approach in Sprite advertisement. The data were in the form of image that collected from the screenshot of the advertisement video. tube and the duration was 30 seconds. In getting the data, the researcher captured each scene of the advertisement video consisting of image, and written text. Then, the researcher transcribed and identified the text and visual information found in the advertisement video. This advertisement was analyzed based on the multimodal theory includes linguistic, visual, audio, gestural, and location analysis (Anstey and Bull 2010; Bateman and Schmidt, 2012; and Chandler, 2007). In particular, linguistic and visual discussions also use the generic structure theory of advertisements proposed by Cheong (2004).

\section{Result and Discussions}

The multimodal discussion of Sprite advertising includes linguistic, visual, audio, gestural, and location analysis (Anstey and Bull 2010; Bateman and Schmidt, 2012; and Chandler, 2007). In particular, linguistic and visual discussions also use the generic structure theory of advertisements proposed by Cheong (2004).

\section{Linguistic Analysis}

The Sprite advertisement, played by two beautiful and handsome teenagers plus one grandfather, uses a combination of spoken and written languages. The speech in this Sprite ad is:

Hey Guys! Ayo berfikir jernih

Nyatanya hidup gak kayak drama korea

[Hujan... Dingiin ...]

Kisah cintanya, gak seunyu yang kamu tonton

Ngarep langsung baik hati sampai bikin kamu meleleh?

[Oppaaa!!!]

[Ya!!!]

Daripada baper sendiri....

Mending mikir jernih bareng Sprite,

Yang nyatanya bening dengan rasa lemon yang nyegerin banget.

Sprite...Nyatanya Nyegerin...

The verbal variety above is an informal variety. This variety is used to eliminate the 'gap' between messages and viewers (consumers) as well as to show the modernity of this advertisement. Furthermore, the emphasis of the meaning contained in the verbal variety of the advertisement is strengthened and emphasized by the presence of written forms which are manifested in the form of visual emblems which are realized through product and trademark emblems. 

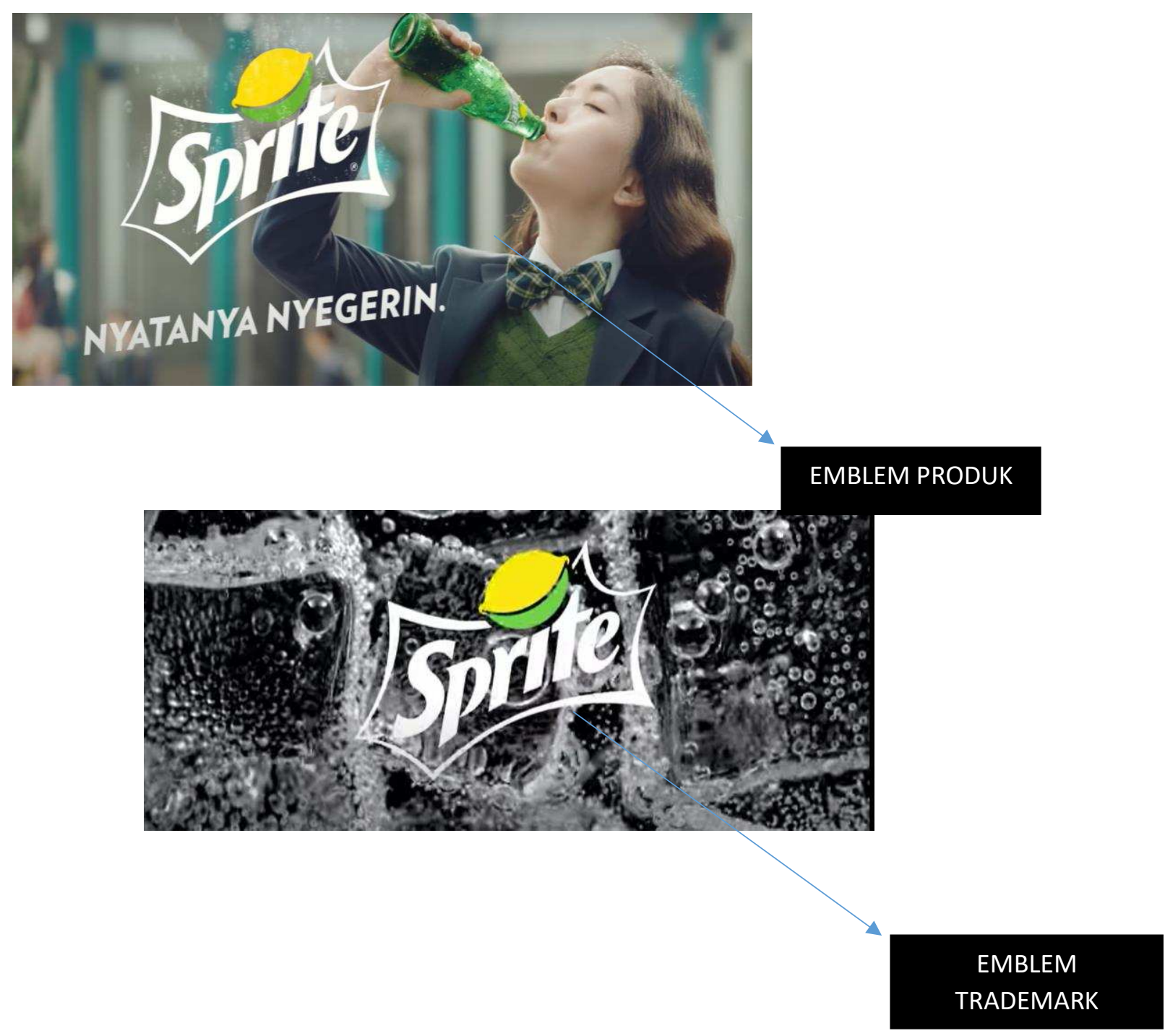

The message in the Sprite advertisement is delivered in the form of an announcement (announcement) which explains that the announcement is the only advertising message, the most important interpersonal aspect among other messages in the text, and the catch phrase aspect. The process that occurred on the announcement as the main message of the advertisement was 'Hey Guys!' Come on think clearly and another invitation sentence, namely 'Sprite, in fact it is cool'. The two processes of greeting and invitation have an imperative mode with commodity goods. This mode is a realization of an invitation to consume beverage products, namely Sprite.

\section{Visual Analysis}

The appearance (visual) in the Sprite advertisement is realized in three visual stages, namely a) the visual of the ad star, b) the visual of the Sprite, and c) the visual emblem. These three visual displays last for 30 seconds. The realization of the three visuals is described in the first image: 


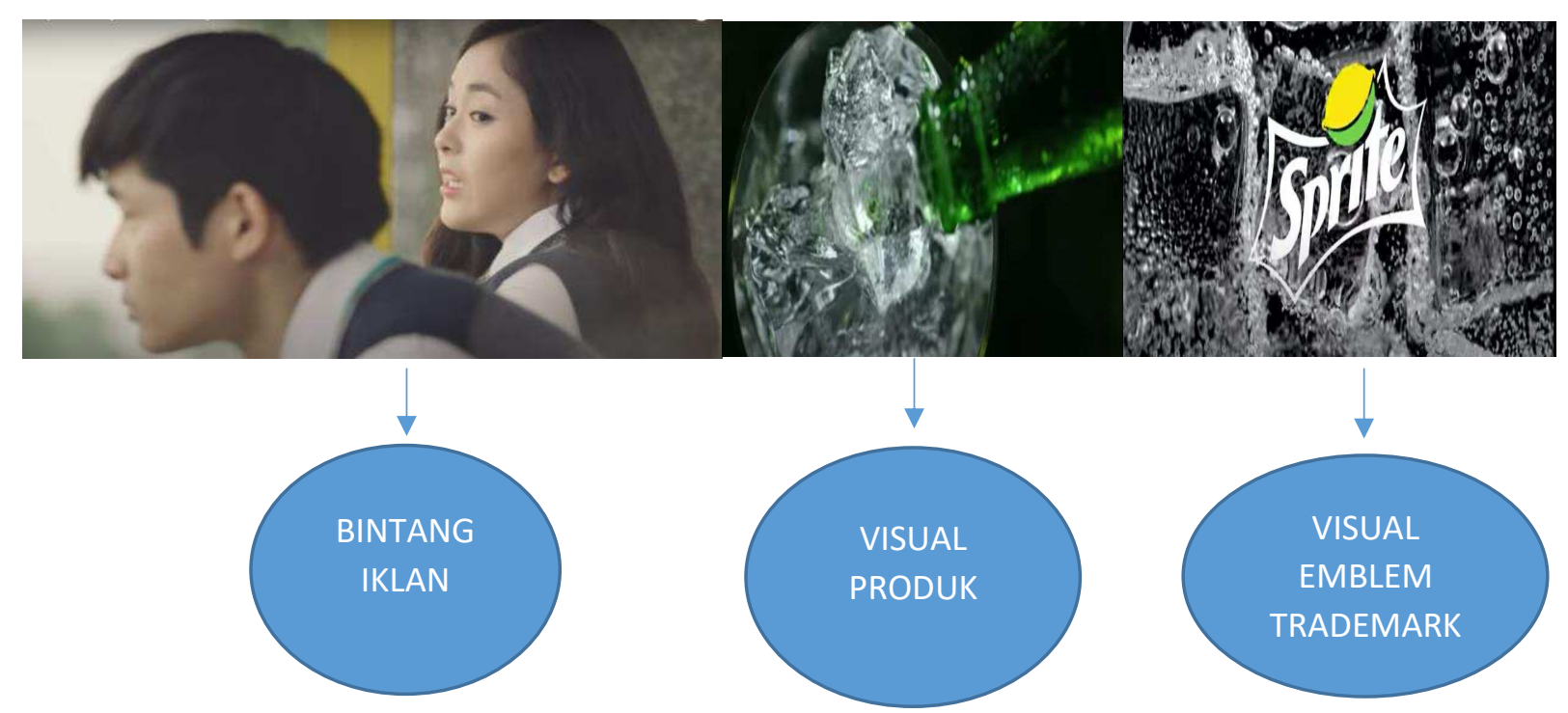

In general, the background of this ad is bright white which can highlight the selected colors that are the core of the image you want to display. Only in the first image, the background is white and black which represents the color of the water and weather in the ad.

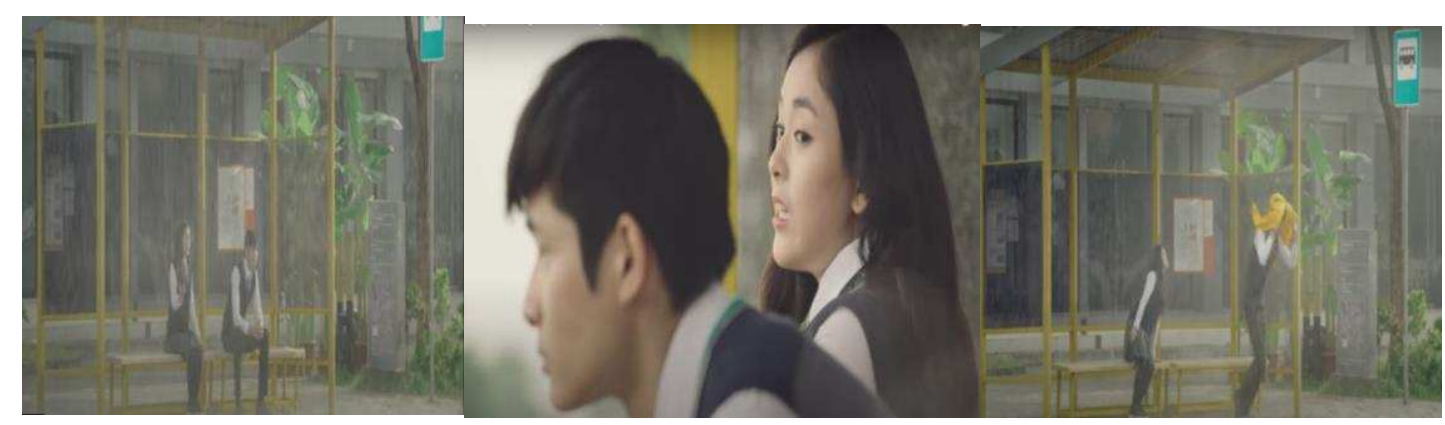

The second picture shows a moving picture that demonstrates a woman who likes a man who is sitting next to her. The location is in a bus stop. The woman expected her love story to be like in Korean dramas, but unexpectedly the love story she expected was very sad. The man left without speaking a word. because the weather at that time was raining.

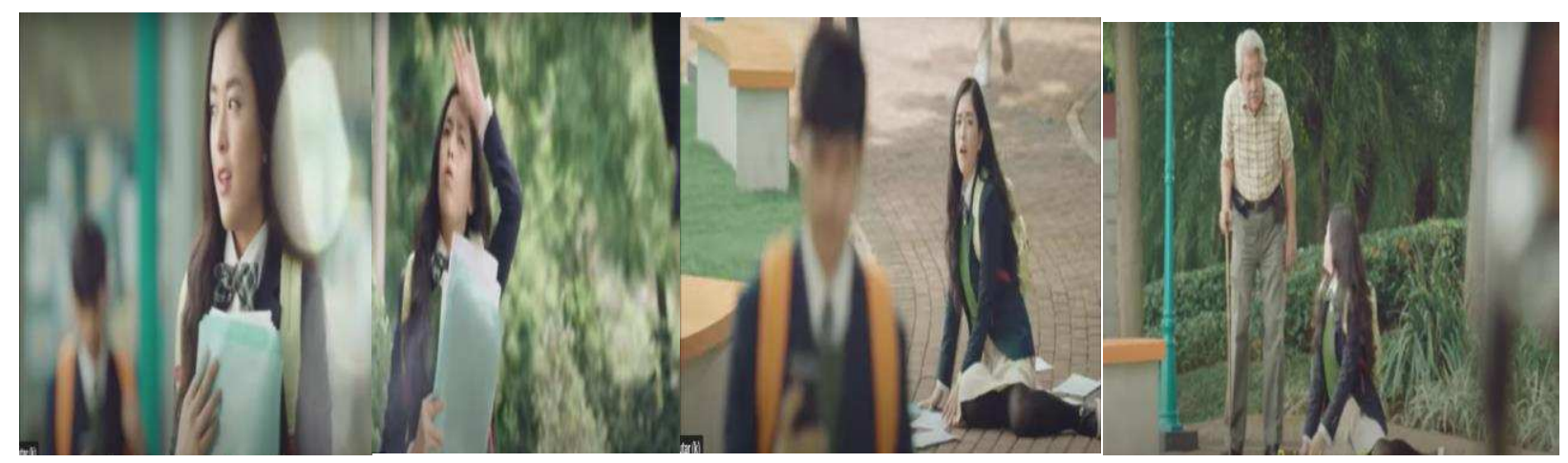


The pictures of the three beautiful women make a strategy for the man she likes to see him and talk to him. By pretending to fall, but it was very unfortunate that the man did not see it and just walked around by playing with the cellphone in his hand. Then the woman started acting like in a Korean drama by calling the man as 'OPPA'. But the one who responded to her summons was an old man saying 'YES'. Then the woman was surprised and looked back with a smile to the grandfather. And hunting left the grandfather.
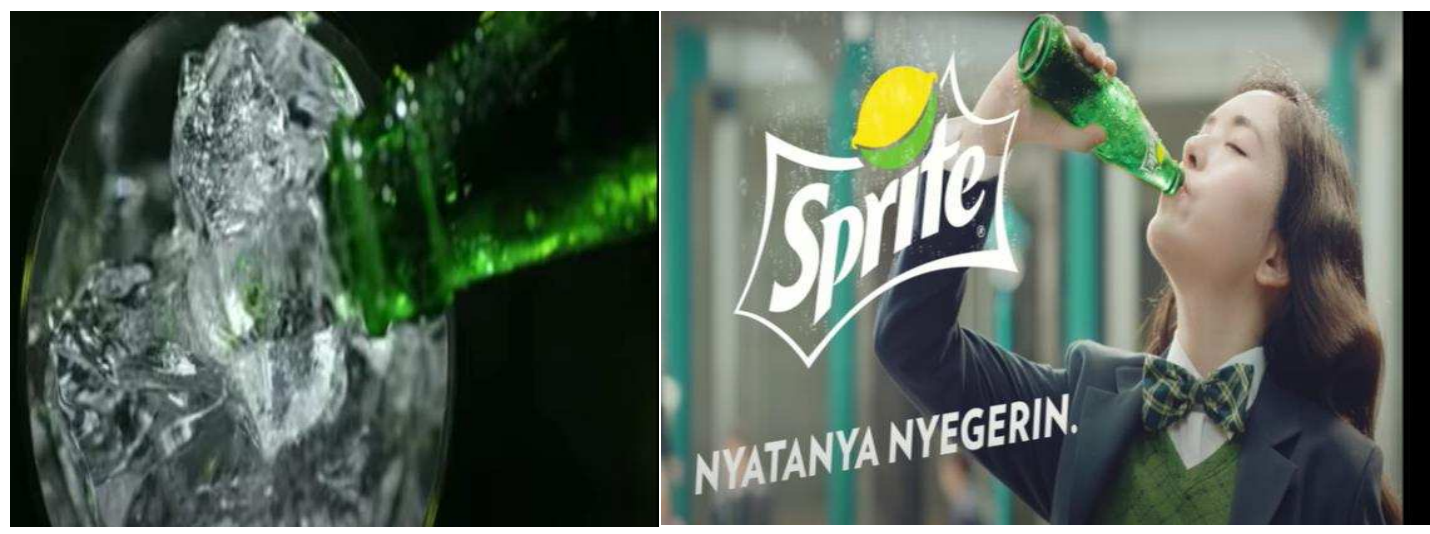

The picture of the four women taking a cold and fresh drink is then drunk. And it hit him that 'SPRITE NYATANYA NYEGERIN'. And forget about all the burdens and Korean dramas he did.

\section{Audio Visual}

The music that accompanies the activities in this commercial is only instrumental music with the genre of melodrama and spirit. This type of advertising music is intended to show / or give the impression that Sprite products can generate strong enthusiasm and are quick to do activities. This is all the more powerful or an affirmation of the superiority of the product.

\section{Gestrual}

The gestures in this advertisement are melodrama and tragi comedic which have the potential to be exploited by gestures. Movement and body speed and facial expressions are the gestures of the participants. Gestures in this advertisement are realized from the activities of the participants in responding to their passionate love life. We can see how a woman is attracted to a handsome man to be her lover. Then the woman pretends to fall to get the man's attention. However, the one who welcomed his call was a grandfather. Hurriedly the woman went and drank the cold Sprite and made him realize that it was not real. Active and passive participants in this advertisement are shown through verbal verbal from active participants daripada baper sendiri...mending mikir jernih bareng Sprite, yang nyata bening dengan rasa lemon yang nyegerin banget. 'SPRITE, NYATANYA NYEGERIN' followed by the written verbal of the product emblem. The process description is realized from the following figure. 


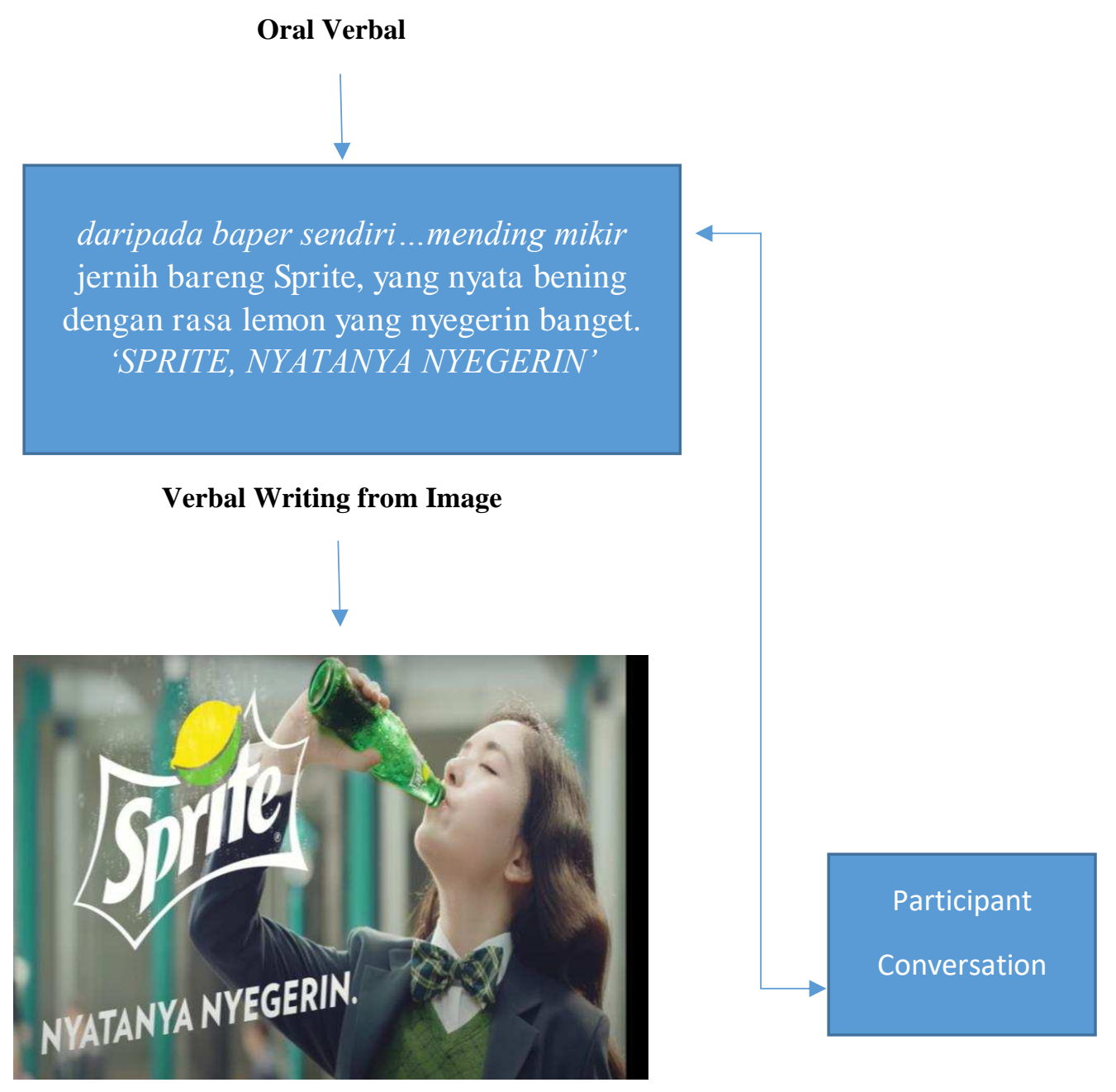

SPATIAL

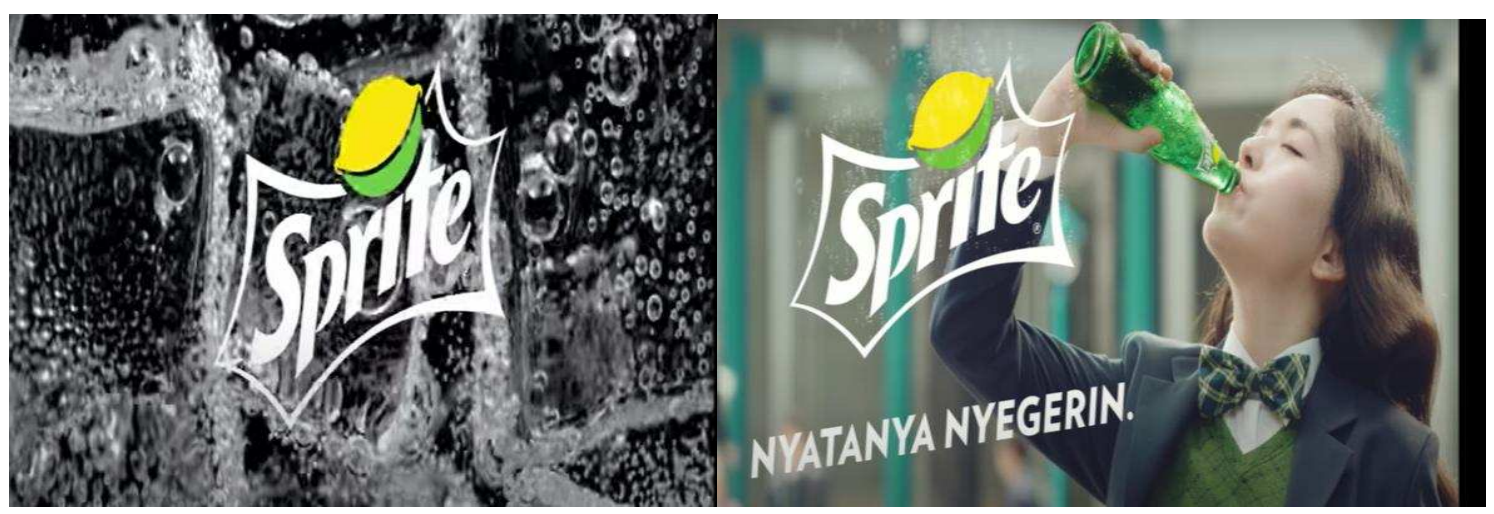


The entire image is generally centered. A large Sprite image is placed in the center and a beautiful woman drinking the Sprite. The language of the inscription "SPRITE" placed in the middle of the ice water made clear the meaning of the whole picture.

\section{CONCLUSION}

SPRITE Advertisement observed has various semiotic elements as included in multimodal discourse analysis. Pesan berbentuk bahasa yang dilakukan melalui bahasa lisan dan bahasa tulisan membuat audiens lebih memahami tentang apa yang sedang dipromosikan. SPRITE advertisement covers the five multimodal semiotic systems, such as linguistic, visual, audio, gestural and spatial. The five semiotics systems blend into one value of bright advertisement.

\section{REFERENCES}

Anstey, Michèle dan Geoff Bull. 2010. "Helping teachers to explore multimodal texts".

Curriculum and Leadership Journal. Vol. 8(16). Dapat diakses di

http://www.curriculum.edu.au/leader/

helping_teachers_to_explore_multimodal_texts,31522.html?issueID=12141.

Bateman, John A. dan Karl-Heinrich Schmidt. 2012. Multimodal Film Analysis: How Films Mean.

New York: Routledge.

Chadler, Daniel. 2007. Semiotics: The Basics. Edisi Kedua. London: Routledge.

Cheong, Yin Yuen. 2004. “The construal of Ideational meaning in print advertisements”. Kay L. O'Halloran (Editor)

Multimodal Discourse Analysis: Systemic-Functional Perspectives.

London: Continuum. Hal. 163 - 195.

Kasali, Rhenald. 1992. Manajemen Periklanan Konsep dan Aplikasinya di Indonesia. Jakarta:

Pustaka Utama Grafiti.

Kay L. O'Halloran (Editor) Multimodal Discourse Analysis: Systemic-Functional Perspectives.

London: Continuum. Hal. 163 - 195.

Kress, G. and van Leeuwen, T. 1996. Reading Images: The Grammar of Visual Design. London: Routledge.

Sinar, Tengku Silvana. 2012. Teori \& Analisis Wacana Pendekatan Linguistik Sistemik

Fungsional. Medan: Mitra. 